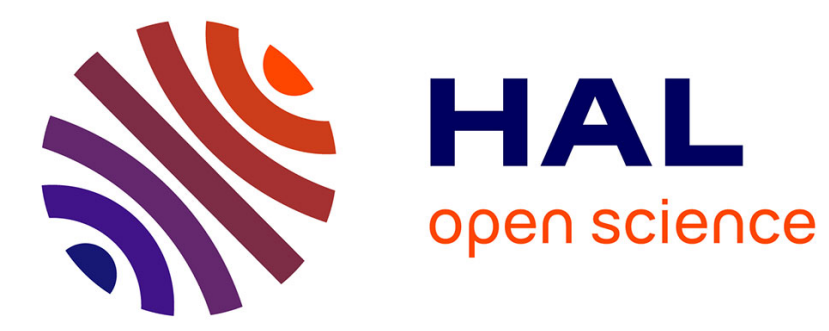

\title{
Longitudinal to transverse drainage network evolution in the High Atlas (Morocco): The role of tectonics
}

Julien Babault, Jean van den Driessche, Antonio Teixell

\section{To cite this version:}

Julien Babault, Jean van den Driessche, Antonio Teixell. Longitudinal to transverse drainage network evolution in the High Atlas (Morocco): The role of tectonics. Tectonics, 2012, 31, pp.TC4020. 10.1029/2011TC003015 . insu-00735591

\section{HAL Id: insu-00735591 https://hal-insu.archives-ouvertes.fr/insu-00735591}

Submitted on 26 Mar 2013

HAL is a multi-disciplinary open access archive for the deposit and dissemination of scientific research documents, whether they are published or not. The documents may come from teaching and research institutions in France or abroad, or from public or private research centers.
L'archive ouverte pluridisciplinaire HAL, est destinée au dépôt et à la diffusion de documents scientifiques de niveau recherche, publiés ou non, émanant des établissements d'enseignement et de recherche français ou étrangers, des laboratoires publics ou privés. 


\title{
Longitudinal to transverse drainage network evolution in the High Atlas (Morocco): The role of tectonics
}

\author{
Julien Babault, ${ }^{1}$ Jean Van Den Driessche, ${ }^{2}$ and Antonio Teixell ${ }^{1}$ \\ Received 31 August 2011; revised 26 May 2012; accepted 1 June 2012; published 14 August 2012.
}

[1] The High Atlas of Morocco is a still-active, linear intracontinental mountain chain in the NW African plate, which results from weak crustal thickening associated with rift inversion during the Cenozoic and from uplift related to mantle thermal doming. A striking morphological feature of the High Atlas is the occurrence of both transverse and longitudinal (i.e., strike-parallel) drainage characterized by deep fluvial incision of more than $1000 \mathrm{~m}$ in low-relief topography of the axial zone of the chain. Most of the transverse component of the drainage appears to postdate the longitudinal component as indicated by recent or incipient captures and wind gaps. The longitudinal drainage is inherited from an early stage of fluvial organization controlled by the tectonic structures developed during upper crustal folding and thrusting in the post-Paleozoic cover. Amplification of N-S regional slope in the western High Atlas by continued crustal shortening and thickening triggered: (i) higher erosion rates in transverse than in longitudinal catchments and (ii) captures of longitudinal streams by transverse ones, creating a new organization of the drainage system toward the regional slope. Such evolution from a longitudinal to a transverse-dominated drainage may represent a common mechanism of fluvial network development in mountain belts where the amplification of the regional slope results from long-lived lithospheric convergence.

Citation: Babault, J., J. Van Den Driessche, and A. Teixell (2012), Longitudinal to transverse drainage network evolution in the High Atlas (Morocco): The role of tectonics, Tectonics, 31, TC4020, doi:10.1029/2011TC003015.

\section{Introduction}

[2] Rivers draining mountain belts follow paths influenced by both mean topographic gradient (or "regional slope") and local surface roughness (or "local slope"). Both tectonics (uplift, crustal thickening, structural deformation) and erosion patterns influence regional and local slopes and drainage patterns can be expected to evolve over orogenic timescales. Incipient orogenic shortening in the upper crust is accommodated by gentle folding and thrusting. These induce local slopes, both parallel and opposite to the regional slope of the mountain belt, which eventually force streams to follow fold axes and thrust faults, i.e., perpendicular to the regional slope [e.g., Koons, 1995]. Ongoing crustal shortening and thickening will cause the amplification of the regional slope and the progressive tilt of the folds and faults developed in the upper crust, decreasing the downstream slopes parallel and opposite to the regional slope. Such evolution of regional and local slopes should favor the progressive capture by

\footnotetext{
${ }^{1}$ Departament de Geologia, Universitat Autònoma de Barcelona, Barcelona, Spain.

${ }^{2}$ Géosciences Rennes, Université de Rennes 1, Campus de Beaulieu, Rennes, France.

Corresponding author: J. Babault, Departament de Geologia, Universitat Autònoma de Barcelona, Despatx C2 124, Barcelona ES-08193, Spain. (julien.babault@uab.es)

Published in 2012 by the American Geophysical Union.
}

transverse streams (via headward erosion) of the longitudinal drains initially controlled by folds and thrust faults.

[3] Authors have long observed the occurrence of both longitudinal and transverse rivers in mountain belts [e.g., Birot, 1970; Bordet, 1955; Davis, 1889; Hovius, 1996; Koons, 1995; Lugeon, 1901; Oberlander, 1965, 1985; Ramsey et al., 2008; van der Beek et al., 2002]. While to Oberlander [1985] the transverse orientation of rivers appeared anomalous, Hovius [1996] remarked that many actively uplifting mountain belts around the world have simple drainage patterns transverse to their main structural trend. A simple explanation to these apparent contradictory views is that they concern orogens that differ in the amount of erosion they suffered, which can be directly related to the regional slope. Oberlander [1985] addressed the Zagros fold and thrust belt, with low shortening (20\%) [McQuarrie, 2004] and regional slope (about $1^{\circ}$ ) [Oberlander, 1965], but relatively strong local slopes, whereas Hovius [1996] is concerned with orogens with much greater crustal shortening and exhumation, involving steeper regional slopes and only weak topographic expression of individual folds and thrusts (e.g., Himalaya, Andes, Southern Alps of New Zealand; etc.). Hence, the pattern in the Zagros can be taken as representative of an early stage of the mountain building process when compared for example to the Himalayas [e.g., Hatzfeld and Molnar, 2010].

[4] We test here the roles of regional and local slopes in controlling the drainage pattern of mountain belts by analyzing the evolution of the main rivers that drain the High 


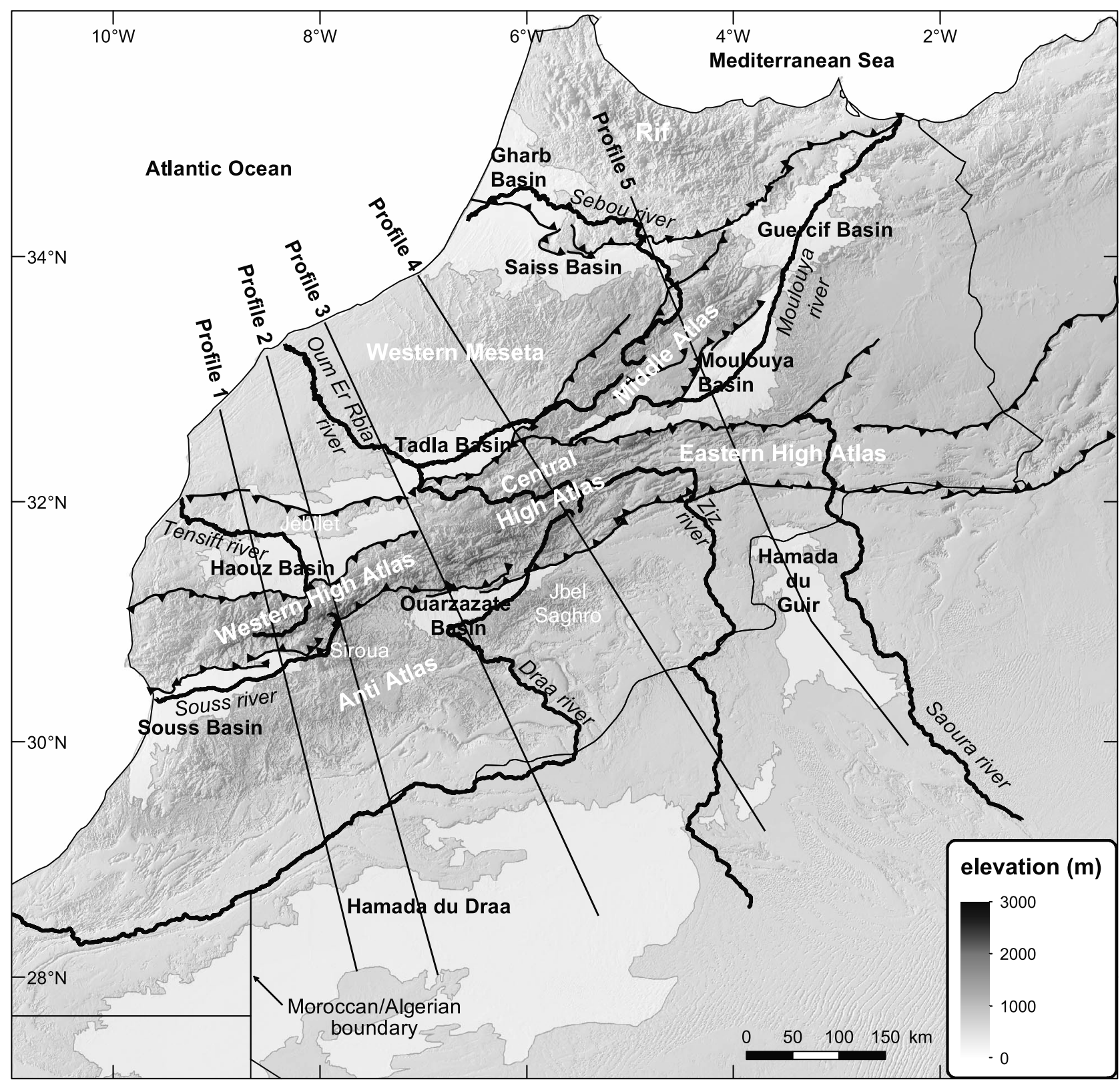

Figure 1. Sketch map showing the main tectonic and topographic features of Morocco. Barbed lines represent the boundaries of the deformed thrust-fold belts of the High Atlas, the Middle Atlas and the Rif. Light gray areas indicate the Cenozoic basins. Profile lines refer to Figure 3.

Atlas mountain belt of Morocco. Variations of structural relief (i.e., the uplift of rock units above their regional, undeformed elevation) and regional surface slope are observed along the strike of the High Atlas, which have favored the selective development of a transverse drainage at the expense of an early longitudinal drainage. Having escaped the effect of glacial erosion due to its low latitudinal position, this mountain belt is particularly appealing for the investigation of the relationships between fluvial drainage networks and tectonics.

\section{Tectonics of the High Atlas}

[5] The ENE-trending High Atlas and the NE-trending Middle Atlas (Figure 1) are Cenozoic intracontinental thrust-fold belts composed at the surface essentially by Mesozoic rocks (mostly carbonate and shale), with sparse Paleozoic and Precambrian basement occurrences (slate, greywacke, rhyolite and granite). The internal structure of the High Atlas is relatively simple, consisting of doubly verging systems of folds and thrust faults, where most of the shortening is concentrated in the orogen margins [Teixell et al., 2003]. No internal crystalline zones developed; on the contrary, the inner parts of the mountain belt are often constituted by tabular sedimentary strata (dominantly Jurassic in age), disrupted by spaced thrusts and folds.

[6] The High Atlas formed after a Triassic-Jurassic rift [Mattauer et al., 1977; Laville and Piqué, 1992; Frizon de Lamotte et al., 2000; Teixell et al., 2003; Arboleya et al., 
2004]. Internal thrusts and folds of the High Atlas trend NE-SW to ENE-WSW, commonly associated to the inversion of former extensional faults. The western High Atlas, south of Marrakech, is dominated by basement exposure, which not only results from differential Atlasic shortening and exhumation, but to the fact the area was originally covered by relatively thin Mesozoic rocks [Balestrieri et al., 2009; Choubert and Faure-Muret, 1962].

[7] Orogenic shortening across the High Atlas is modest (15-25\%) [Teixell et al., 2003]. Crustal thickening is also moderate, and cannot account for its high elevation [Ayarza et al., 2005; Makris et al., 1985; Wigger et al., 1992]. The occurrence of Cenozoic alkaline magmatism and a geophysical modeling suggested that the elevation is partly supported by an abnormally thin lithosphere [Missenard et al., 2006; Teixell et al., 2003; Teixell et al., 2005; Zeyen et al., 2005], probably as a result of deep thermal upwelling.

[8] Based on syntectonic sediments, the age of crustal shortening in the High Atlas is placed from mid Eocene to Quaternary times [see a recent review in Tesón et al., 2010, and references therein], while geomorphic evidence suggests that much of the mantle-related surface uplift $(\sim 1000 \mathrm{~m})$ occurred in post-Miocene times [Babault et al., 2008].

\section{Analysis of Topography and Sources of Uplift}

[9] We describe the topography of the Atlas mountains and surroundings by their mean elevation at crustal and lithospheric scale, calculated in moving windows of 30 or $100 \mathrm{~km}$ of diameter, respectively. The elevation data used for the analysis is the SRTM90v4 DEM (A. Jarvis et al., 2008, Hole-filled SRTM for the globe, version 4, available at http://srtm.csi.cgiar.org). In temperate regions and under slow to moderate erosion rates $(\sim<0.2 \mathrm{~mm} / \mathrm{yr})$, hillslope erosion rates have been shown to be dependent on mean basin slopes and local relief [e.g., Montgomery and Brandon, 2002; Ouimet et al., 2009]. Indeed, local relief measured at $5 \mathrm{~km}$ scales is more a reflection of channel steepness than hillslope gradient and correlates with erosion rate up to $1 \mathrm{~mm} / \mathrm{yr}$ [DiBiase et al., 2010]. Accordingly, we calculated the local relief (maximum minus minimum elevation) in a 5-km-moving window (Figure 3), and we used it as a proxy to identify regions of probable high and low erosion rates.

[10] The High Atlas of Morocco is $700 \mathrm{~km}$ long and 50 to $120 \mathrm{~km}$ wide. In $26 \%$ of the chain the mean elevation at $30 \mathrm{~km}$ scale is higher than $2000 \mathrm{~m}$ asl (Figure 2a). This high land is $\sim 440 \mathrm{~km}$ long and $>20 \mathrm{~km}$ wide in the western part of the High Atlas (SW of Marrakech) and up to $>70 \mathrm{~km}$ wide around Imilchil, at $6^{\circ} \mathrm{W}$ (Figures 2a and 3, profiles 2 and 4). Only $2.6 \%$ of the Moroccan High Atlas is at a mean elevation that exceeds $2600 \mathrm{~m}$.

[11] The foreland basins flanking the High Atlas lie at low elevation in the west $(\leq 500 \mathrm{~m}$, Haouz, Souss and Tadla basins, Figures 1 and 2a), whereas in the south-central part and the east they correspond to plateaux at $1200-1400 \mathrm{~m}$ asl (Ouarzazate, Moulouya and Hamada du Guir, Figures 1 and 2a). These elevated plains have not been shortened during the Cenozoic. The mean elevation at $100 \mathrm{~km}$ scale shows a 400-km-long swell higher than $1500 \mathrm{~m}$ asl and reaching values above $\sim 2100 \mathrm{~m}$ asl that extends from the Anti-Atlas to the Middle Atlas. These high elevations are slightly oblique to the mean tectonic trend of the High Atlas (Figure 2b).

[12] The highest values of mean elevation at $30 \mathrm{~km}$ scale coincide with the areas affected by crustal shortening during the Cenozoic (Figures 2a and 3). In the absence of systematic estimates of the depth to the Mohorovicic discontinuity, the negative Bouguer gravity anomaly in these areas reveals that shortening is accommodated at depth by crustal thickening (Figures $2 \mathrm{a}$ and 3 ).

[13] The superposition of the mean elevation contour lines at $100 \mathrm{~km}$ scale fit well the NE-trending asthenospheric doming (Figures $2 \mathrm{~b}$ and 3). Mantle-related surface uplift has affected the High and Middle Atlas deformed belts, and is responsible for the high elevation above $1200 \mathrm{~m}$ a.s.l. of the Anti-Atlas and the Ouarzazate and Moulouya basins as well (Figure 2a). The crustal shortening [Teixell et al., 2003] and lithospheric thinning [Fullea et al., 2007; Missenard et al., 2006; Teixell et al., 2005; Zeyen et al., 2005] explain well the distribution of the mean elevation in the central and eastern High Atlas. However, the western High Atlas and the low-elevation Haouz and Souss foreland basins lie outside the maximum lithospheric thinning [Missenard et al., 2006]. Therefore, much of the high mean elevations in the western High Atlas must be sustained by crustal thickening.

\section{Analysis of the Drainage Pattern of the High Atlas}

\subsection{Drainage Network Organization}

[14] The northern flank of the High Atlas is drained to the Atlantic by the Tensift and the Oum Er Rbia rivers in the west, and to the Mediterranean by the Moulouya river in the east (Figure 1). Along the southern flank, the main rivers from west to east are the Souss, the Draa and the Ziz (Figure 1). The Ziz river ends in the Sahara desert while the outlets of the Souss and the Draa rivers reach the Atlantic (although the Draa river is actually not perennial and water often evaporates or infiltrates before reaching the ocean).

[15] Along much of the northern flank from $5^{\circ} \mathrm{W}$ to $8^{\circ} 30^{\prime} \mathrm{W}$ and along the southern flank from $5^{\circ} \mathrm{W}$ to $6^{\circ} 30^{\prime} \mathrm{W}$, trunk streams are dominated by reaches parallel to the trend of the chain (Figure 4a), termed here "longitudinal" reaches. The length of these main rivers ranges between $30 \mathrm{~km}$ to more than $150 \mathrm{~km}$. On the northern flank of the western High Atlas, longitudinal reaches are principally located in the highest part of the chain (Nfiss, Ourika and Zate rivers, Figure 4a) and they flow to the ENE. A marked change occurs east of $7^{\circ} \mathrm{W}$ (Figure 4a); the longitudinal reaches of the Tessaout, Guemez and Melloul rivers, localized also in the interior of the chain, flow to the WNW, opposite to the flow of the Nfiss, Ourika and Zate longitudinal reaches. The Abid river, a tributary of the Melloul, has also a large longitudinal reach that in this case appears localized close to the mountain front.

[16] On the southern flank of the High Atlas, from the western termination of the chain to the longitude of Ouarzazate, most rivers are transverse (Figure 4a). Although drainage is mainly transverse north of the Ouarzazate basin, the course of the main rivers, i.e., the Dadès and the upper reaches of the Mgoun river, are almost parallel or slightly oblique to the trend of the orogen (Figure 4a). Some rivers of the smaller catchments localized north of Ouarzazate are 

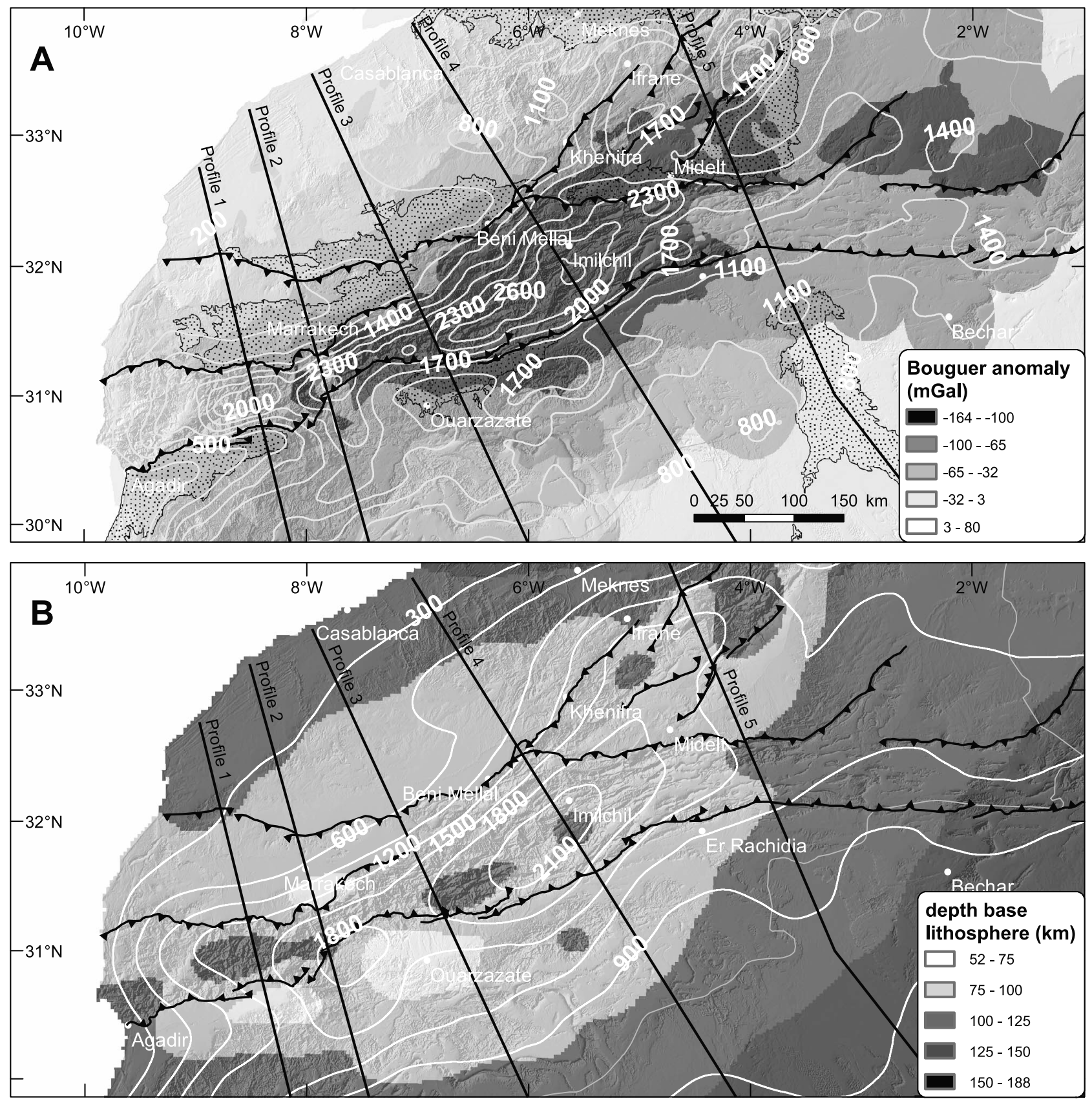

Figure 2. Shaded relief maps of the High Atlas region indicating the main tectonic features (thrust fronts bounding the deformed belts) and (a) the Bouguer gravity anomaly and contours of mean elevation calculated at crustal scale, i.e., in a $30 \mathrm{~km}$ moving window, (b) the depth to the lithosphere/asthenosphere boundary [after Fullea et al., 2007] and contours of the mean elevation calculated at lithospheric scale, i.e., in a $100 \mathrm{~km}$ moving window.

also characterized by longitudinal reaches (Figure 4a). The Ziz river and its main tributaries (Figure $4 \mathrm{a}$ ) are also characterized by long reaches parallel to the trend of the chain.

\subsection{Relationship Between Drainage Pattern, Structure, Lithology, and Regional Slope Values}

[17] In the central and eastern High Atlas, the previously described longitudinal reaches are all parallel to the structural grain, as defined by map-scale folds and thrust fronts (Figure $4 \mathrm{~b}$ ). Most of the transverse reaches connecting the longitudinal streams correspond to fold terminations or transfer faults. In Figures $5 \mathrm{a}$ and $5 \mathrm{~b}$, we project the main rivers on 3-D diagrams constructed with geologic crosssections of the High Atlas and the shaded topography. These diagrams illustrate that in most of the High Atlas, longitudinal rivers flow along the axis of large synclines of the folded and faulted Mesozoic cover. There are strong contrasts of erodability; the most resistant layers generally form the crest of the narrow anticlines, while wide synclines are frequently occupied by weak shale formations. 

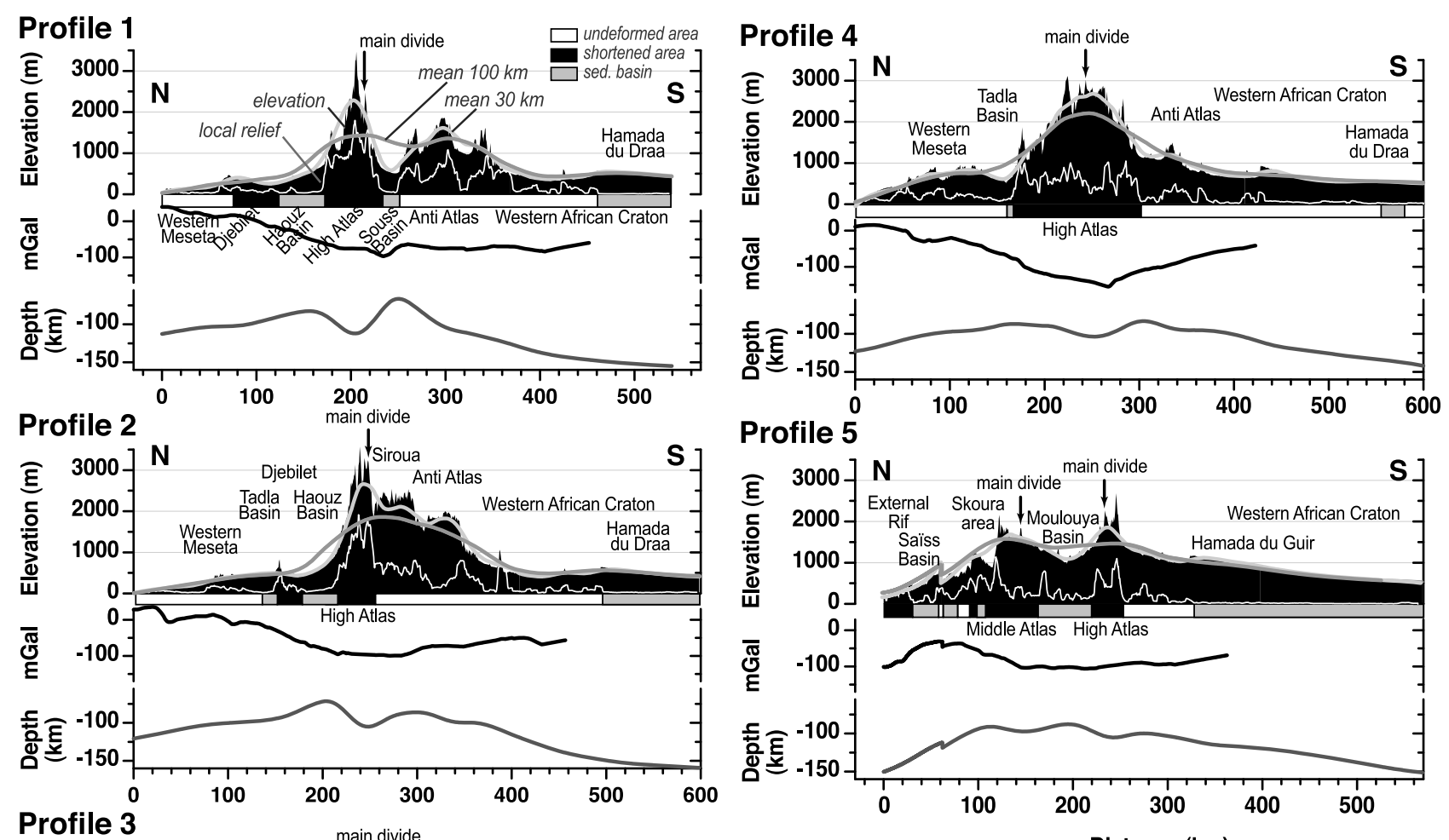

Profile 5
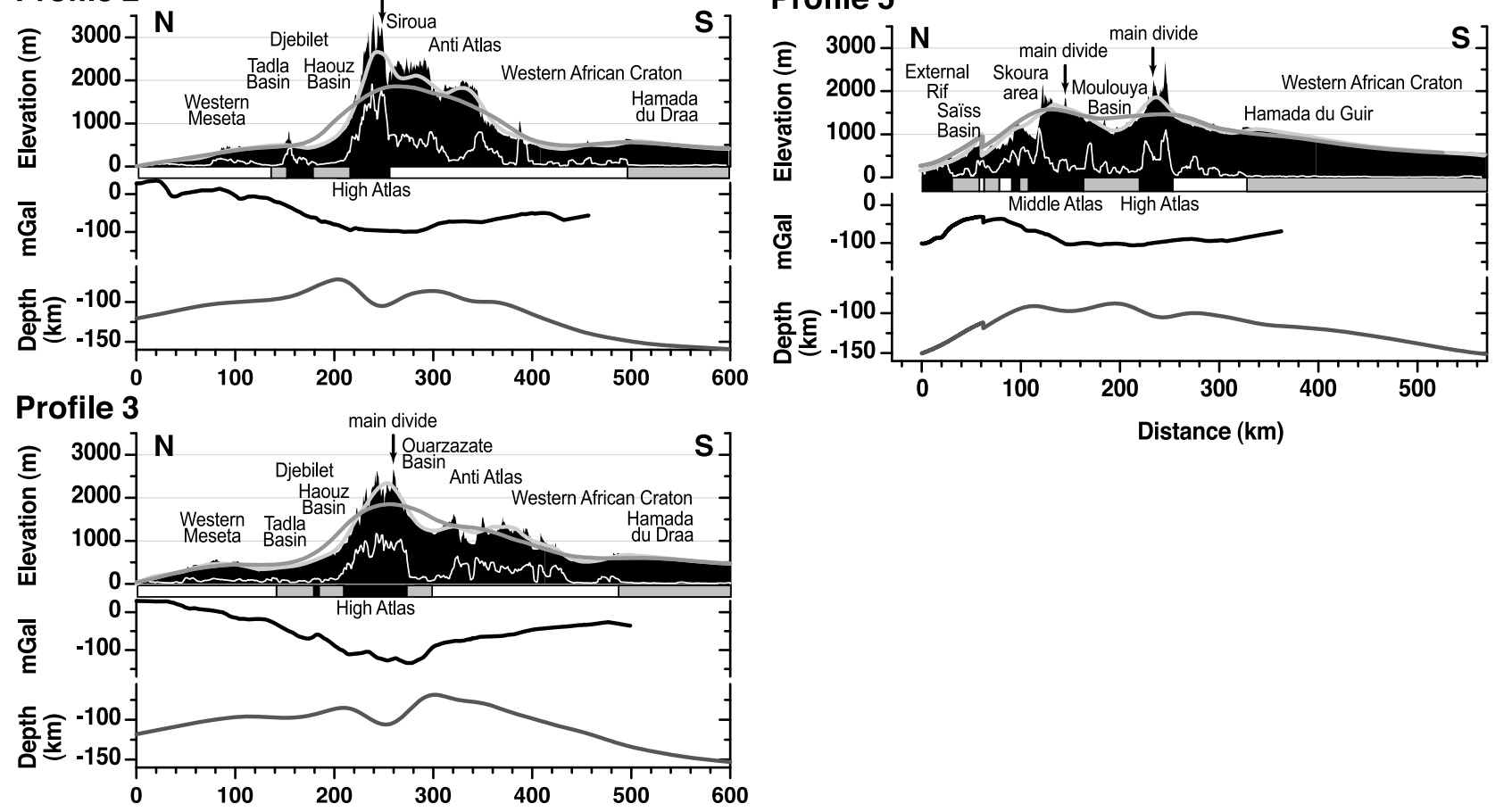

Figure 3. Profiles transverse to the Atlas chains indicating the actual topography (black area), the mean elevation calculated in a $30 \mathrm{~km}$ moving window (light gray line), the mean elevation calculated in a $100 \mathrm{~km}$ moving window (dark gray line), the local relief (thin white line), and, below the topographic profiles, the Bouger gravity anomaly (in $\mathrm{mGal}$ ) and the depth to the lithosphere/asthenosphere boundary as indicated in Figure $2 \mathrm{~b}$ (see Figure 2 for profile location).

[18] In the western High Atlas (Toubkal Massif), the Our$\mathrm{ika}$ and Zate rivers follow the structural grain of the chain in the axial zone in spite of being made of Precambrian to Paleozoic magmatic and metamorphic rocks. The longitudinal segment of the Ourika river coincides with the trace of a main fault parallel to the general trend of the chain, suggesting a structural control of the river orientation. Similarly, it is plausible that the longitudinal reaches of the Ourika and Zate rivers formed originally in synclines of a now eroded Mesozoic cover. More to the west, the Nfiss river flows parallel to the trend of the chain in granitic basement and in a syncline of Triassic sedimentary rocks. These Triassic rocks are the remnants of an inverted graben now preserved only in the lower part of the longitudinal reach of the Nfiss river (Figure 5b). This suggests that sediments covered the western High Atlas and that their folding controlled the development of a longitudinal drainage in same way as it does to the east where the folded and faulted sedimentary cover is preserved.
[19] Where the main rivers cut through the outer parts of the western High Atlas, they follow the regional slope across structures. This is the case for the transverse reaches of the Ourika and Zate rivers in the northern flank of the chain. Regional slope values were calculated using the grid of mean elevation at $30 \mathrm{~km}$ scale. The correlation between slope angles and the drainage network is shown in Figure 4c; this map shows that rivers are transverse at least in 4 specific areas where the regional slope value is greater than $3^{\circ}$. By contrast, longitudinal rivers flow where the regional slope is less than $2.5^{\circ}$.

\subsection{Azimuth Distribution of Main Rivers Versus Regional Slope Direction Distribution}

[20] In order to evaluate to what degree rivers follow the regional slope, we plotted the azimuth of flow for each main river (and for each set of neighboring rivers with a similar planform geometry) and the regional slope in polar diagrams 

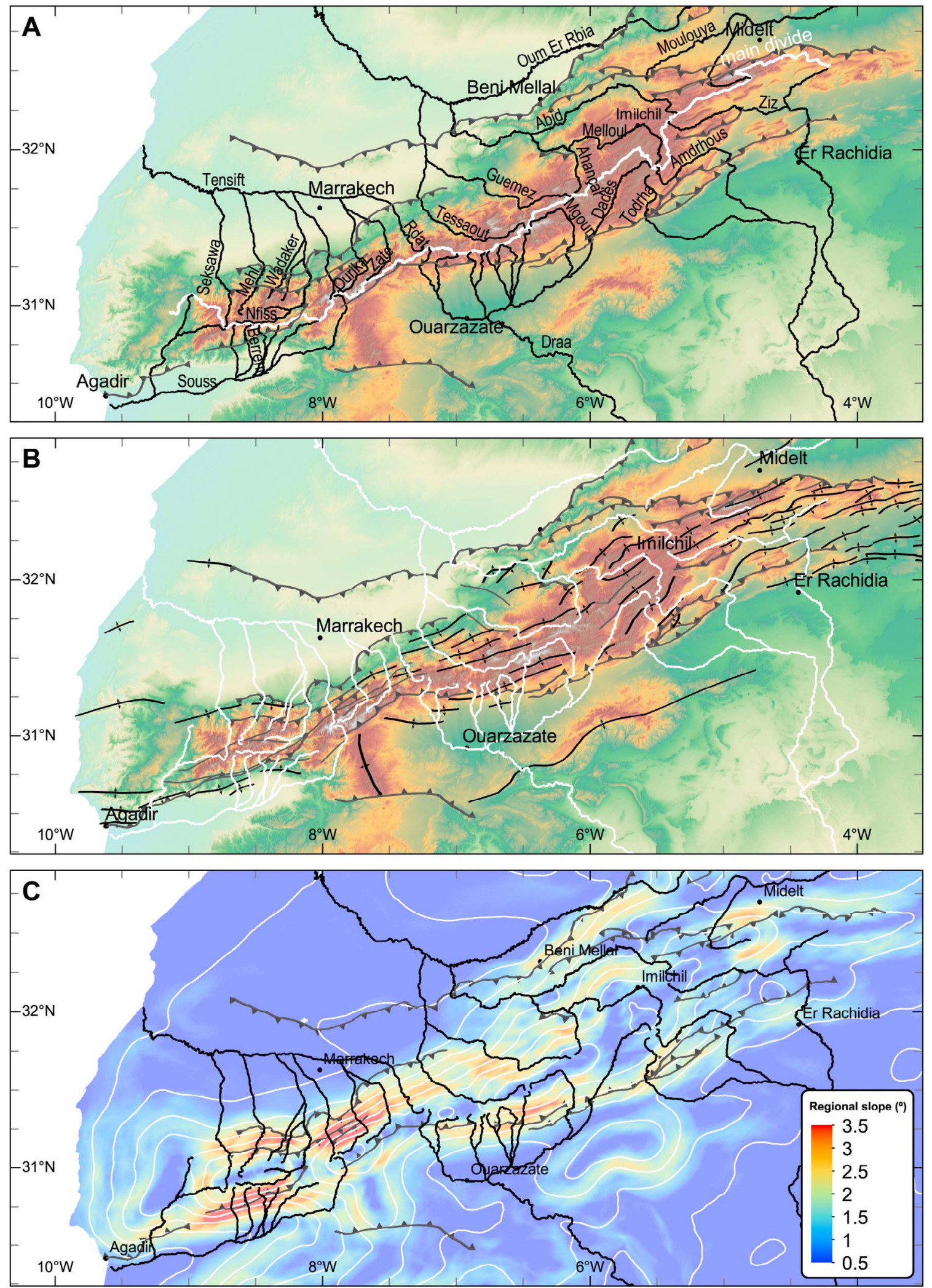

Figure 4. (a) Shaded relief map of the High Atlas region including the projection of the principal rivers and the trace of the main divide. (b) Tectonic sketch map representing the main folds and thrust fronts. (c) Map of the drainage network superimposed to the regional slope, calculated using the grid of mean elevation at $30 \mathrm{~km}$ scale. Contours indicate the mean elevation calculated in a $30 \mathrm{~km}$ moving window. 

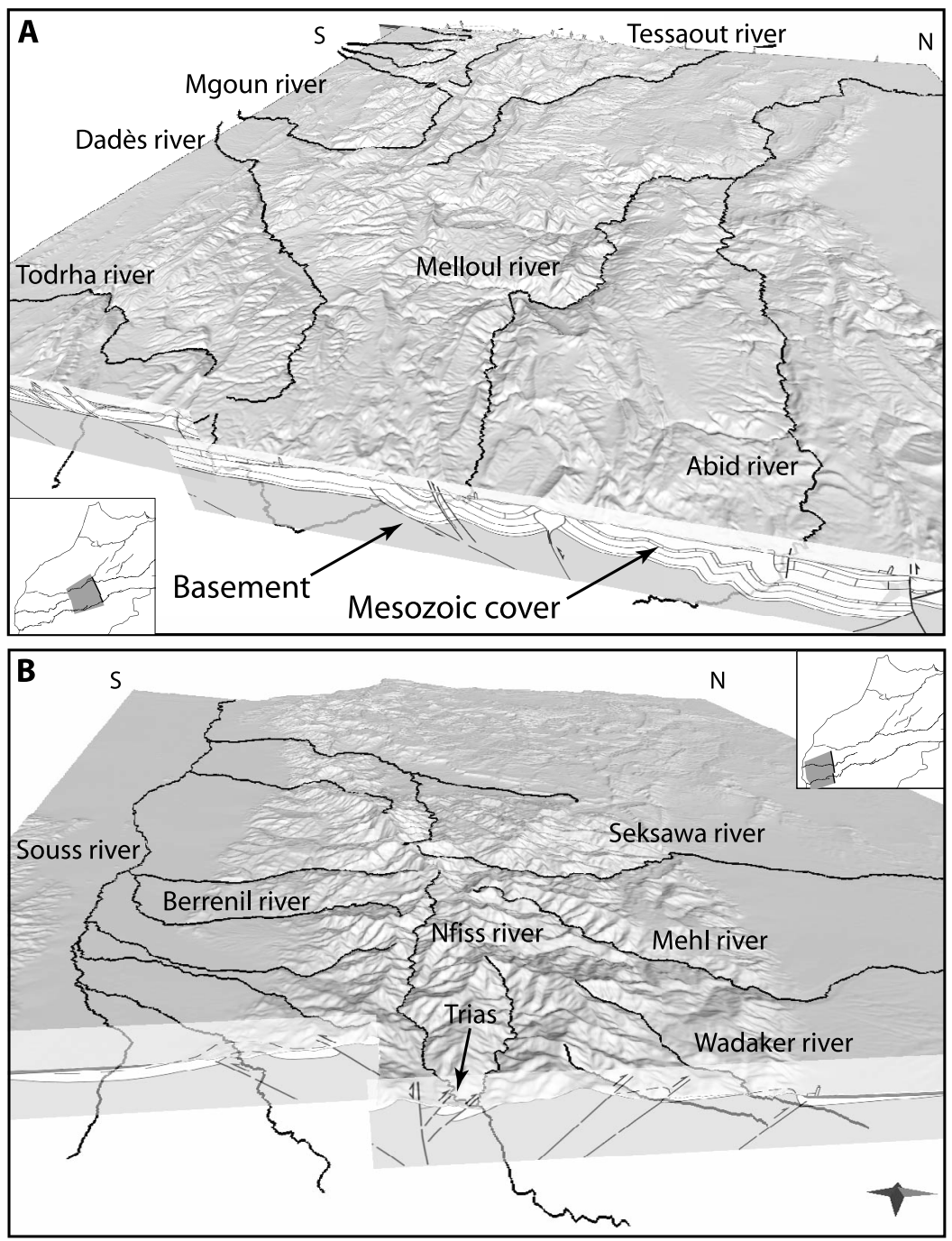

Figure 5. 3-D along-strike views of the topography and the cross-sectional structure of the (a) central and (b) western High Atlas. The longitudinal reaches of the main rivers are preferentially located in between anticlinal or thrust ridges. Figure 5a represents a view west of the Imiclchil section of Teixell et al. [2003], whereas Figure $5 \mathrm{~b}$ represents a view west of a transect through the Tizi n'Test area. Transverse rivers become more prominent in Figure 5b, which exhibits higher structural relief and extensive exposure of exhumed basement.

(black histograms in Figure 6). River flow azimuths were extracted using the D8 flow routing [O'Callaghan and Mark, 1984] in RiverTools (L. L. C. Rivix, Rivertools 3.0, 2003, available at http://www.rivertools.com), and each pixel $(90 \mathrm{~m} \times 90 \mathrm{~m})$ of the main river paths has been sampled (" $n$ " in Figure 6 is the number of sampled pixels). Because DEM grids are usually north-south, east-west oriented rectangles, D8 flow routing only allows the computation of eight azimuths ranging from $0^{\circ}$ to $315^{\circ}$ and spaced by intervals of $45^{\circ}$. Circular mean directions [Fisher, 1993] have also been calculated (black dots in polar diagrams).

[21] We computed the azimuth distribution of the main regional slope where those rivers flow by extracting the flow angles of the smoothed topography, i.e., the mean elevation at $30 \mathrm{~km}$ scale. Accordingly, we used the Mass Flux Method of RiverTools (L. L. C. Rivix, Rivertools 3.0, 2003, available at http://www.rivertools.com), because the smoothed topography, which has a dome-like shape, is convex up. We sampled the azimuths of the smoothed topography along the main river paths. The continuous flow angle of the regional steepest slope directions have been binned at intervals of $15^{\circ}$ following Fisher [1993], starting at $-7.5^{\circ}$ and ending at $352.5^{\circ}$ (gray histograms in Figure 6). The circular mean direction has also been calculated for each sample (gray dots in polar diagrams). The resulting composite diagrams of Figure 6 allow determining three types of catchments in the High Atlas with regard to the percentage of reaches (of pixel size) of the main rivers that flow in the regional slope: longitudinal-dominated, transverse-dominated and mixed.

[22] Within a given catchment, the proportion of streams that flow in the main regional slope direction may vary from $11 \%$ to $58 \%$. In the sub-catchments in white in Figure 6, the proportion of river reaches that flow parallel to the regional slope is high $(40 \%, 41 \%, 47 \%$ and $58 \%$, for Tensift west, Ouarzazate west, Tensift Ighighayene-Rdat, 


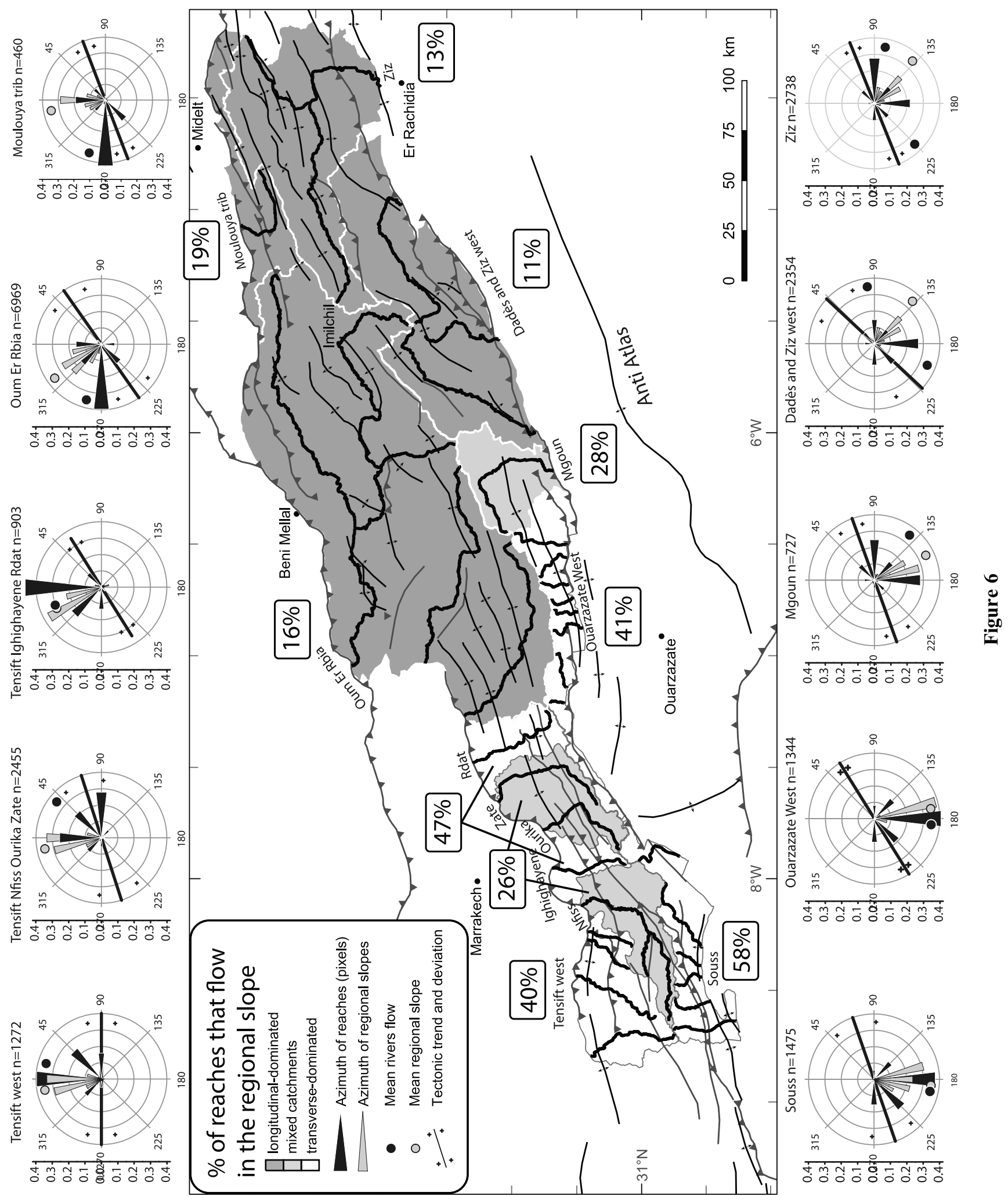


and Souss subcathments, respectively). These catchments are mainly characterized by transverse streams. By contrast, in the sub-catchments in dark gray in Figure 6, the proportion of reaches that follow the regional slope is low $(11 \%$, $13 \%, 16 \%$ and 19\%, for Dadès and Ziz west, Ziz, Oum Er Rbia, and Moulouya tributary sub-catchments, respectively). We classify these catchments as longitudinal-dominated. The difference between the mean river flow direction and the mean regional slope in these is at least $45^{\circ}$.

[23] In the sub-catchments in light gray in Figure 6, the proportion of reaches that follow the regional slope is between $26 \%$ and $28 \%$ (Tensift-Nfiss-Ourika-Zate, and Mgoun subcatchments). Longitudinal and transverse reaches develop respectively in the upstream and downstream parts of these mixed catchments.

[24] For each subcatchment, the polar diagrams of Figure 6 report the main trend of the tectonic structures (faults and folds), and the deviation from the main tectonic trend of the High Atlas. The orientation of the structures is almost everywhere perpendicular to the main regional slope, and the longitudinal-dominated catchments have a high percentage of reaches (of pixels) that flow subparallel to the main folds and faults.

[25] In summary, most of the catchments of the central and eastern High Atlas are longitudinal-dominated, whereas transverse-dominated catchments prevail in the western High Atlas south of Marrakech, with mixed catchments to a lesser extent.

\section{Drainage Reorganization}

[26] The western High Atlas shows impressive jagged relief where the drainage is transverse, with steep slopes and a mean local relief at $5 \mathrm{~km}$ scale of more than $1100 \mathrm{~m}$ (profiles 1 and 2, Figure 3). Hillslope processes are dominated by landslides (shallow and deep) and rockfalls (e.g., in the southern flank in Figure 7a). On the other hand, the central and eastern High Atlas has a mean local relief of $900 \mathrm{~m}$, and of only $600 \mathrm{~m}$ at profiles 4 and 5 (Figure 3). The landscape of the latter is smooth with a few canyons (e.g., Melloul river, $30 \mathrm{~km}$ west of profile 4, and Dadès, Todhra and Ziz rivers at the southern flank).

[27] In spite of the jagged relief that characterizes the western High Atlas in general, the longitudinal reaches close to the headwaters of the Nfiss, Ourika and Zate rivers exhibit a remarkably smooth landscape. In these upstream reaches, local relief ranges from 100 to $600 \mathrm{~m}$ (Figures $7 \mathrm{~b}$ and 8 ). The low-relief, upstream reaches of the longitudinal catchments are surrounded by local slopes of more than $30^{\circ}$ in the highrelief, transverse catchments. Landslides in the upstream areas of the transverse valleys cut the smooth topographies producing a retreat of the divide and reducing the width of the longitudinal catchments in both flanks (Figures 7 and 8). The longitudinal drainage basins of the Nfiss, Ourika and Zate rivers become narrower in their upstream reaches (to the west) and beyond the western divide of the Nfiss and Ourika catchments streams are transverse.

[28] The presence of a longitudinal catchment along the main divide area and of transverse catchments on each side causes the occurrence of triple-junctions of divides (Figure $7 \mathrm{~b}$ and 8 ). In those places the remnants of longitudinal streams are preserved as wind gaps indicating they previously extended upstream before having been captured. Such wind gaps are very common along the divides bordering the longitudinal rivers. They are characterized by strong slope asymmetry, the lower slope being always directed toward the longitudinal catchment, and the greater slope toward the transverse one. This indicates that the upstream parts of the tributaries of the main longitudinal trunks have also been captured by the transverse catchments (Figures 7a, 9a, and 9b). Ongoing captures of the narrow, low-relief, longitudinal upstream reaches will lead to the disappearance of the old divides and the creation of a new main divide separating transverse catchments.

[29] Applying this scheme to the parts of the main divide that separate transverse catchments, it follows that originally a longitudinal catchment was probably separating the northern and southern flanks of the mountain chain.

[30] From this drainage evolutionary pattern we infer a shift toward the center of the High Atlas of $\sim 10-15 \mathrm{~km}$ of the divides that lie between the transverse rivers of both flanks and the Nfiss axial longitudinal catchment (Figure 7b). Values of divide shifts are lower $(\sim 7-8 \mathrm{~km})$ in the upper Ourika river and in the upper Zate river $(<3 \mathrm{~km})$ (Figure 8$)$.

\section{Discussion}

\subsection{Mechanisms Causing a Fluvial Drainage Reorganization in the High Atlas}

[31] Fluvial captures all over the western High Atlas indicate that the drainage network systematically evolves from longitudinal-dominated to transverse-dominated. In what follows we discuss potential mechanisms that may be causing this process of fluvial drainage reorganization at the scale of the mountain chain.

[32] Differences in erodibility due to spatial variations in rock strength can explain differential erosion rates between catchments and local changes in drainage organization, as it happens in some areas of the Zagros fold and thrust belt [Oberlander, 1985] though not everywhere [Ramsey et al., 2008]. However, the upper reaches of the longitudinal Nfiss and transverse Berrenil rivers of the High Atlas (Figure 7a) are both located within a granitic massif without lithological changes (Tichka granite), indicating that rock strength is not influencing the process of divide retreat and capture. Diverse lithologies compose the western High Atlas, the main being Precambrian rhyolite and granite, and Paleozoic slate, greywacke and granite. Major variations of lithology are perpendicular to the main trend of the chain. However, we systematically observe captures of longitudinal

\footnotetext{
Figure 6. Polar diagrams of the flow direction of main river reaches in the High Atlas and of the regional slope direction within the same catchments. The subcatchments Tensift west, Ouarzazate west, Tensift Ighighayene-Rdat, and Souss are mainly characterized by transverse streams. The Dadès and Ziz west, Ziz, Oum Er Rbia and Moulouya tributary subcatchments are classified as longitudinal-dominated. In the Tensift-Nfiss-Ourika-Zate and Mgoun subcatchments, longitudinal and transverse reaches develop respectively in the upstream and downstream parts of these mixed catchments. The polar diagrams also report the main trend of the tectonic structures (faults and folds), and the deviation from the mean.
} 

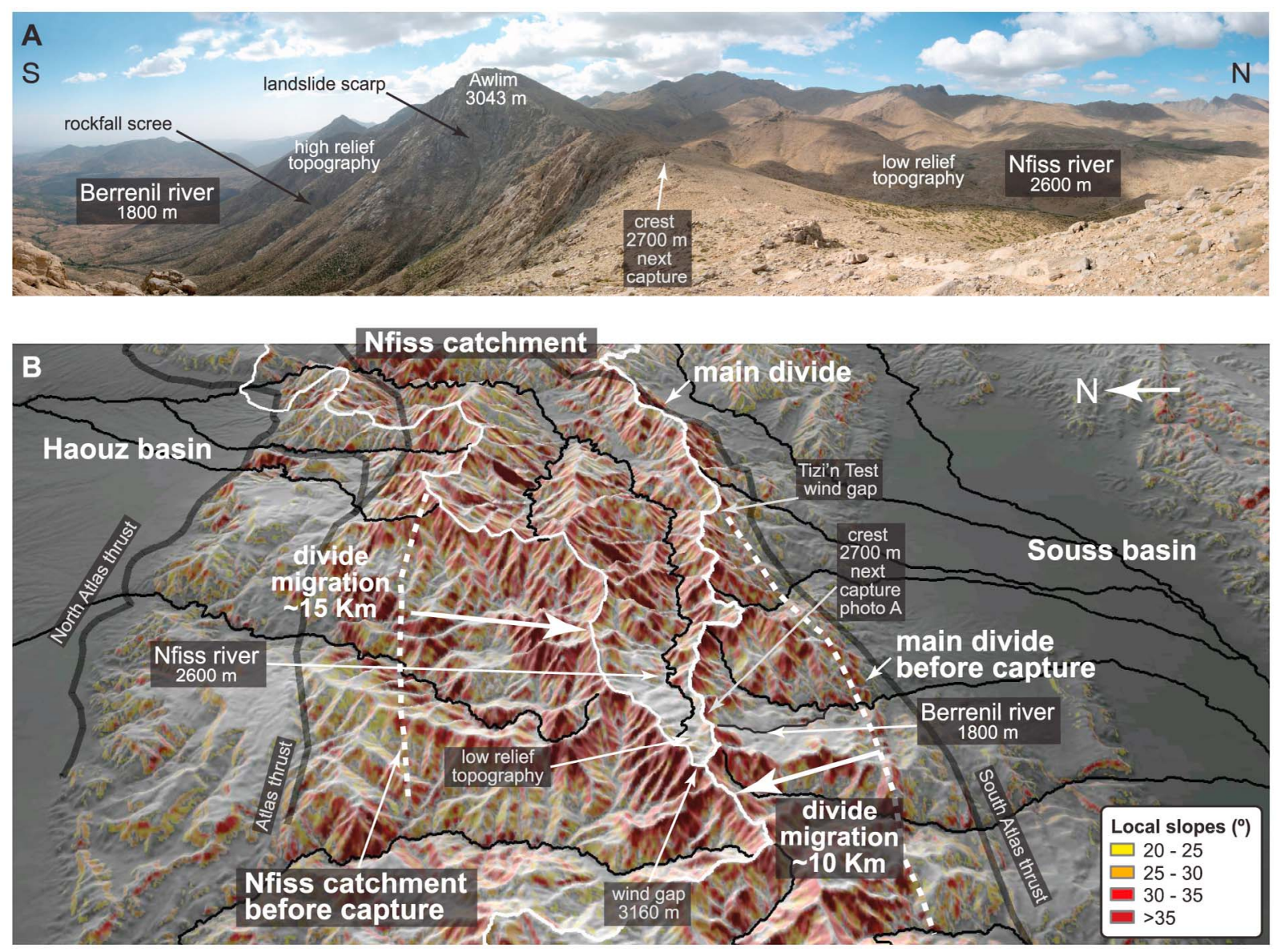

Figure 7. (a) Field image of the upstream parts of the Nfiss longitudinal river and the Berenil transverse river, in the western High Atlas (see location of rivers in Figure 4a). The southern slope of the divide is very steep with local relief of $1000 \mathrm{~m}$, whereas local relief is only $150 \mathrm{~m}$ on the northern side. Landslides and rockfalls are common in the steep hillslopes. (b) 3-D view to the east of the upstream reach of the Nfiss longitudinal river, which is characterized by high elevation (above $2600 \mathrm{~m}$ ) and low local relief $(300 \mathrm{~m})$. The color scale indicates local slopes. Landslides in the upstream areas of the transverse valleys cut the smooth topographies producing a retreat of the divide and reducing the width of the longitudinal catchments in both flanks. Remnants of longitudinal streams are preserved as wind gaps indicating they previously extended upstream before having been captured.

reaches by transverse streams over $\sim 200 \mathrm{~km}$ of the higher part of the western High Atlas, which indicates that lithology is not the dominant control on drainage reorganization in the western High Atlas.

[33] Erosion is proportional to water flux, and earlier studies proposed that precipitation gradients perpendicular to an orogen may lead to the migration of the main divide toward the drier flank [e.g., Bonnet, 2009; Willett, 1999]. The only gradients of precipitation that occur in the western High Atlas at the scale of the orogen are from east to west, due to the westerlies that supply moisture laterally from the Atlantic Ocean, and from the lowlands to the uplands, i.e., orographic rainfall enhancement [MADRPM, 2000]. On the assumption that these modern patterns of moisture and precipitation held in the recent past, and since captures occur on both flanks, the systematic drainage network evolution from longitudinal-dominated to transverse-dominated is not controlled by asymmetric precipitation.

[34] In mountain belts in the northern hemisphere, glacial headwall retreat of the glaciated north-facing sides of valleys during the Pleistocene have induced a migration of east-west trending ridgelines toward the unglaciated, south-facing side [e.g., Naylor and Gabet, 2007]. However, glacial erosion in the Toubkal massif could not explain the observed captures facing south. Moreover, the equilibrium line altitude (ELA) in the coldest stages of the Pleistocene was at $3300 \mathrm{~m}$ asl [Dresch, 1941; see also references in Hughes et al., 2011, 2006], leaving only $0.6 \%$ of the High Atlas above the ELA and hence under glacial conditions for erosion. Consequently, drainage reorganization cannot either be a consequence of glacial erosion in the High Atlas, which is dominated by fluvial erosion.

[35] The position of the longitudinal network correlates with the structural grain of the Mesozoic cover in the central and eastern High Atlas (Figures 4b, 5, and 6) with longitudinal reaches that are mainly confined in wide synclines or in front of anticline-related thrusts. In these segments of the chain the regional slope is low, mostly below $2.5^{\circ}$ (Figure $4 \mathrm{c}$ ). In contrast, transverse-dominated rivers spatially correlate with regional slopes ranging from $3^{\circ}$ to $5^{\circ}$ (Figure $4 \mathrm{c}$ ), with high 


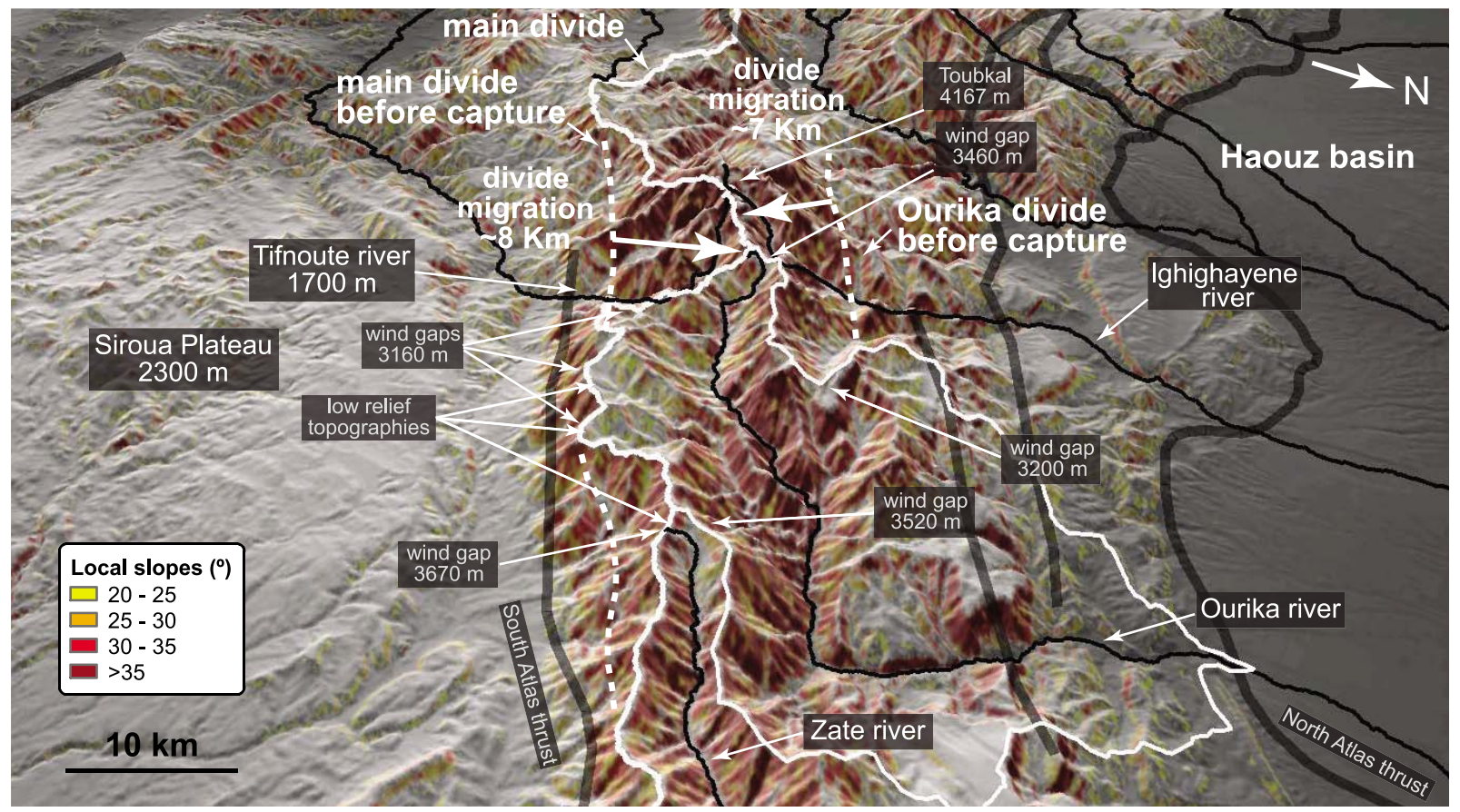

Figure 8. Shaded relief view to the east of the upstream reach of the Ourika longitudinal valley (western High Atlas), characterized by high elevation (above $2600 \mathrm{~m}$ ) and low local relief (300 m). Landslides in the upstream parts of the transverse valleys cut the smooth topographies producing a retreat of the divide and reducing the width of the longitudinal catchments in both flanks. Remnants of longitudinal streams are preserved as wind gaps indicating they previously extended upstream before having been captured.

local valley slopes (high local relief at $5 \mathrm{~km}$ scale, Figure 3), and with very active hillslope erosion evidenced by landslides (Figure 7), suggesting a threshold for aggressive headward migration and drainage capture by transverse systems. Greater erosion during the Cenozoic in the western High Atlas is also evidenced by Miocene apatite fission track ages with respect to preorogenic Cretaceous and older ages in the central and eastern High Atlas [Balestrieri et al., 2009; Barbero et al., 2007; Missenard et al., 2008]. Hence, the western High Atlas can be seen as an equivalent of the eastern High Atlas but with more structural relief of basement units, greater regional slope, and deeper exhumation that has largely removed the Mesozoic cover, all these specific features resulting from more rock uplift. We conclude that the mean regional slope is left as the main factor that can explain the drainage reorganization from longitudinal to transverse-dominated rivers in the High Atlas mountains.

[36] Modeling based on potential fields [Missenard et al., 2006] and surface data [Babault et al., 2008] argue for a maximum $1000 \mathrm{~m}$ of mantle-related surface uplift of the Atlas system, decreasing on both sides of the elongated thermal lithospheric anomaly (Figure $2 b$ ). The wavelength of this uplift (hundreds of $\mathrm{km}$ ) is far too large, compared to the width of the western High Atlas, to have triggered the drainage reorganization in this narrow segment of the chain.

\subsection{A Model for Landscape Evolution in the High Atlas Inversion Orogen}

[37] The study of the Atlas system shows that the drainage network in an intracontinental mountain belt resulting from the inversion of a rift may experience an evolutionary trend from longitudinal to transverse. In the early stages of inversion, shortening produced folds and thrusts in the sedimentary cover more or less decoupled from basement which kept a low and homogeneous structural elevation. The previously stretched nature of the crust prevented its rapid overthickening and the establishment of high mean elevations and regional slopes. Under these circumstances, local structures produced sufficient local relief to deflect the rivers and make them flow parallel to the structural grain (Figure 10a). Ongoing shortening increased crustal thickening to exceed values acquired during the rifting phase. Flexural isostatic response to thickening increased the mean elevation of the orogen and the regional slopes on both flanks. Consequently, increased potential energy on both sides of the deformed belt enhanced fluvial erosion in short transverse rivers. Progressively, the differential erosion rates between the longitudinal rivers in the center of the chain and the transverse rivers made the latter capture longitudinal reaches and at the same time increase their contributing area. Ongoing thickening and drainage reorganization continuously reinforced transverse rivers' capacity of erosion by increasing slopes and drainage areas. This process should eventually lead to the complete destruction of the early longitudinal drainage (Figure 10b). Hence, the incision rates in the main rivers ultimately control drainage evolution. If incision equals rock uplift rates then surface uplift stops (provided that hillslope erosion rates equal fluvial erosion) and the regional slopes no longer increase. In such conditions, the drainage reorganization can be expected to freeze even if longitudinal reaches are still preserved in the core of the orogen.

[38] This model of drainage evolution agrees with the observation that most of rivers in evolved mountain belts are 

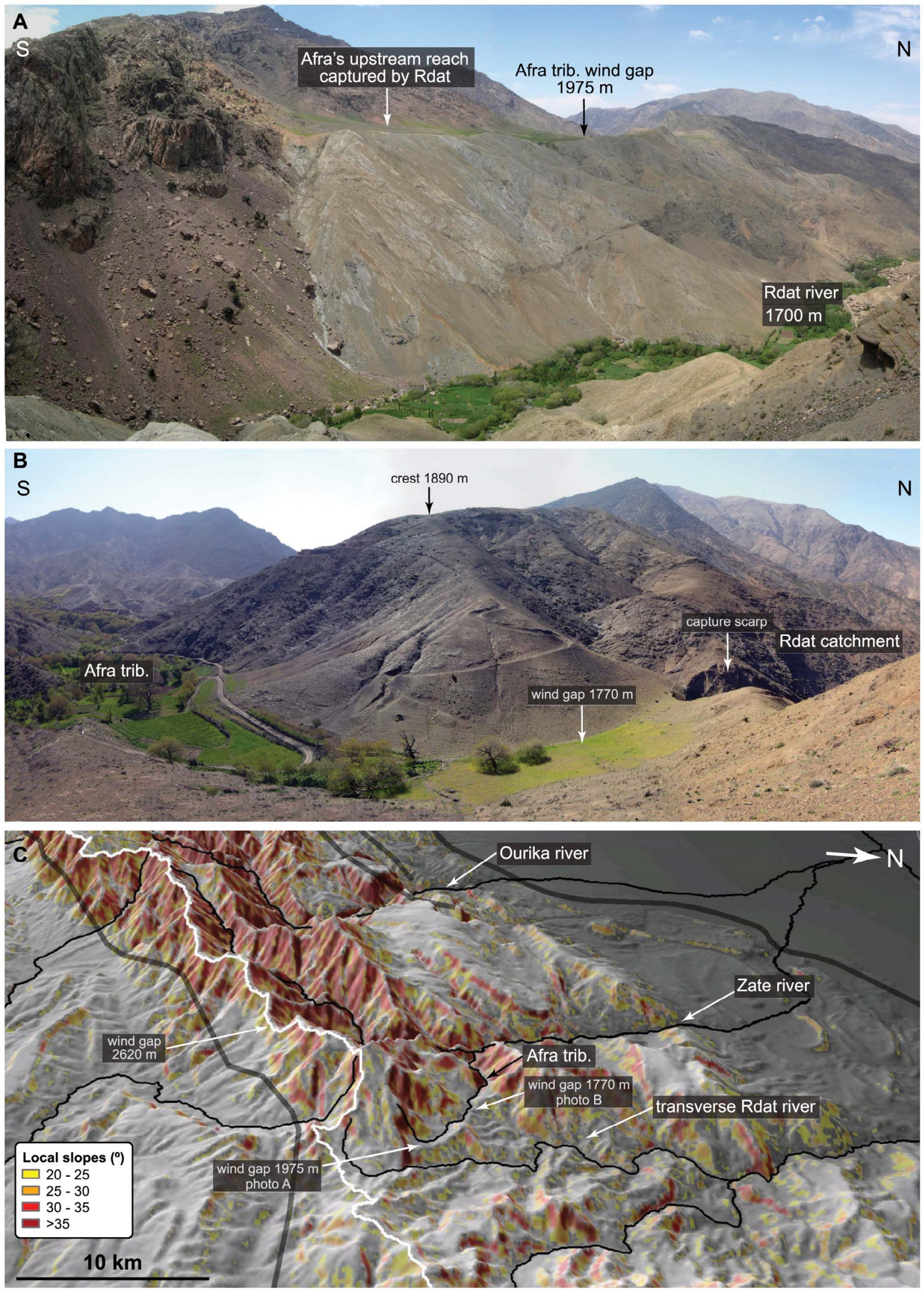

Figure 9. ( $a$ and b) Field images and (c) shaded relief view of the piracy of a longitudinal tributary of the Zate river by the Rdat (transverse) river near the Tichka pass (western High Atlas). Color in Figure 9c indicates the local slopes as in Figure 8. 


\section{A. Early rift inversion}

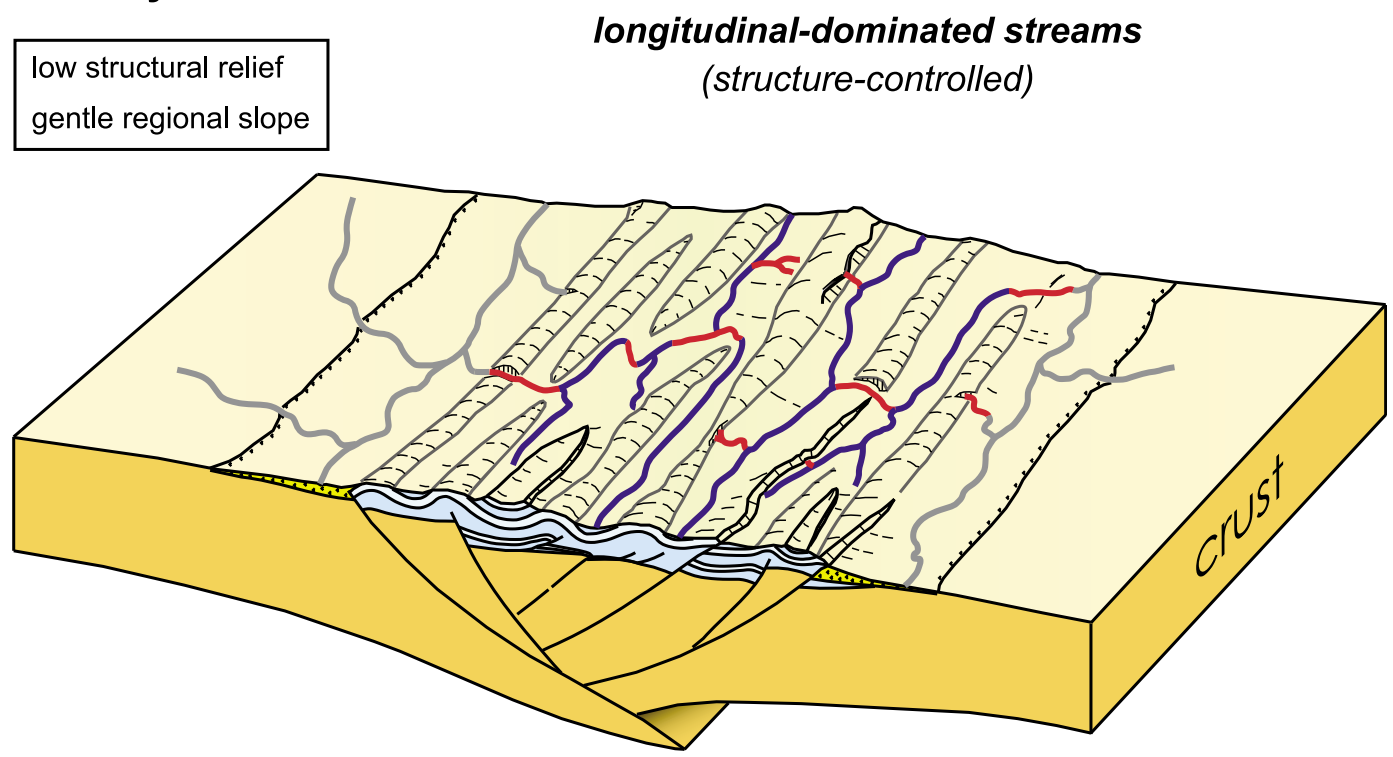

\section{B. Mature inversion}

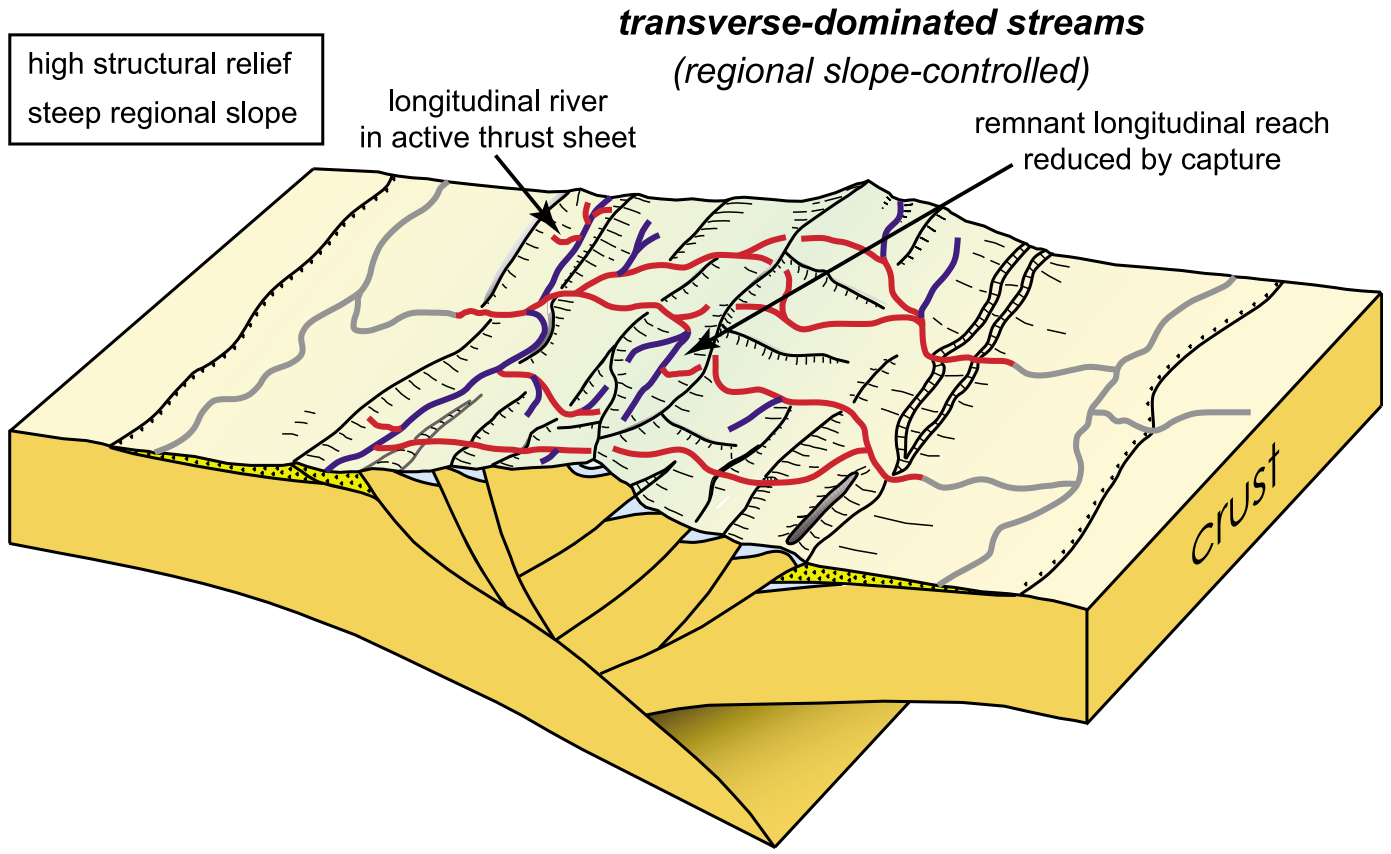

Figure 10. Block diagrams illustrating two stages of fluvial drainage versus tectonic structure and regional slope in orogens formed by rift inversion. The evolution from longitudinal to transverse drainage is characteristic of the transient stage of drainage systems in growing mountain belts. Longitudinal streams are shown in blue, whereas transverse streams are indicated in red.

transverse whatever the climatic conditions [Hovius, 1996]. The evolution from a longitudinal to a transverse drainage can be considered as a transient stage of drainage evolution during mountain building.

\section{Conclusion}

[39] While the eastern and central High Atlas, with lower elevation and regional slopes, are dominated by longitudinal (i.e., strike-parallel) drainage, fluvial captures all over the western High Atlas of Morocco indicate that the drainage network systematically evolves from longitudinal-dominated to transverse-dominated. Lithology and climate are not the dominant control on drainage reorganization in the High Atlas, leaving the mean regional slope as the dominant factor.

[40] We propose that increased tectonic thickening and surface uplift enhanced potential energy on both sides of the deformed western High Atlas and enhanced the fluvial 
erosion in short transverse rivers. The differential erosion rates between the longitudinal rivers in the center of the chain and the transverse rivers in the margins made the latter capture longitudinal reaches and at the same time increase their contributing area. Ongoing thickening and drainage reorganization continuously reinforced transverse rivers capacity of erosion by increasing slopes and drainage areas. This process will inevitably lead to the complete destruction of the early longitudinal drainage in the western High Atlas and also in the eastern High Atlas if deformation and uplift continue at the present rates.

[41] Our study suggests that the evolution from a longitudinal to a transverse drainage in orogenic belts is a transient stage of drainage evolution during mountain building.

[42] Acknowledgments. This work was supported by the Ministerio de Educación y Ciencia projects (CGL2006-07226 and CGL2010-15416), the Consolider Ingenio 2006 TOPOIBERIA (CSD2006-00041), and the TOPOMED project (CGL2007-66431-CO2-01). We thank two anonymous reviewers, the associate editor and the editor, Onno Oncken, for their constructive comments and suggestions that have contributed to the improvement of the manuscript. We thank Alain Crave, Geoffrey Ruiz, and François Negro for help and discussion during field campaigns and María Luisa Arboleya for discussion and support.

\section{References}

Arboleya, M. L., A. Teixell, M. Charroud, and M. Julivert (2004), A structural transect through the High and Middle Atlas of Morocco, J. Afr. Earth Sci., 39(3-5), 319-327, doi:10.1016/j.jafrearsci.2004.07.036.

Ayarza, P., F. Alvarez-Lobato, A. Teixell, M. L. Arboleya, E. Tesón, M. Julivert, and M. Charroud (2005), Crustal structure under the central High Atlas Mountains (Morocco) from geological and gravity data, Tectonophysics, 400(1-4), 67-84, doi:10.1016/j.tecto.2005.02.009.

Babault, J., A. Teixell, M. L. Arboleya, and M. Charroud (2008), A Late Cenozoic age for long-wavelength surface uplift of the Atlas Mountains of Morocco, Terra Nova, 20(2), 102-107, doi:10.1111/j.1365-3121. 2008.00794.x.

Balestrieri, M. L., G. Moratti, G. Bigazzi, and A. Algouti (2009), Neogene exhumation of the Marrakech High Atlas (Morocco) recorded by apatite fission-track analysis, Terra Nova, 21(2), 75-82, doi:10.1111/j.13653121.2008.00857.x.

Barbero, L., A. Teixell, M.-L. Arboleya, P. del Rio, P. W. Reiners, and B. Bougadir (2007), Jurassic-to-present thermal history of the central High Atlas (Morocco) assessed by low-temperature thermochronology, Terra Nova, 19(1), 58-64, doi:10.1111/j.1365-3121.2006.00715.x.

Birot, P. (1970), Les Régions Naturelles du Globe, 380 pp., Masson, Paris.

Bonnet, S. (2009), Shrinking and splitting of drainage basins in orogenic landscapes from the migration of the main drainage divide, Nat. Geosci., 2(12), 766-771, doi:10.1038/ngeo666.

Bordet, P. (1955), Les éléments structuraux de l'Himalaya de l'Arun et de la région de l'Everest (Nepal oriental), C. R. Hebd. Seances Acad. Sci., 240(1), 102-104.

Choubert, G., and A. Faure-Muret (1962), Evolution du domaine atlasique marocain depuis les temps paleozoïques, in Livre à la Mémoire $d u$ Professeur Paul Fallot, pp. 447-514, Soc. Géol. de Fr., Paris.

Davis, W. M. (1889), The Rivers and Valleys of Pennsylvania, pp. 183-253, Nat. Geogr. Soc., Washington, D. C.

DiBiase, R. A., K. X. Whipple, A. M. Heimsath, and W. B. Ouimet (2010), Landscape form and millennial erosion rates in the San Gabriel Mountains, CA, Earth Planet. Sci. Lett., 289(1-2), 134-144, doi:10.1016/ j.eps1.2009.10.036.

Dresch, J. (1941), Recherches sur l'Évolution du Relief dans le Massif Central du Grand Atlas, le Haouz et la Souss, 712 pp., Imprim. Arrault, Tours, France.

Fisher, N. I. (1993), Statistical Analysis of Circular Data, 277 pp., Cambridge Univ. Press, Cambridge, U. K., doi:10.1017/CBO9780511564345.

Frizon de Lamotte, D., B. Saint Bezar, R. Bracène, and E. Mercier (2000), The two main steps of the Atlas building and geodynamics of the western Mediterranean, Tectonics, 19(4), 740-761, doi:10.1029/2000TC900003.

Fullea, J., M. Fernandez, H. Zeyen, and J. Verges (2007), A rapid method to map the crustal and lithospheric thickness using elevation, geoid anomaly and thermal analysis. Application to the Gibraltar Arc system, Atlas Mountains and adjacent zones, Tectonophysics, 430(1-4), 97-117.
Hatzfeld, D., and P. Molnar (2010), Comparisons of the kinematics and deep structures of the Zagros and Himalaya and of the Iranian and Tibetan plateaus and geodynamic implications, Rev. Geophys., 48(2), RG2005, doi:10.1029/2009RG000304.

Hovius, N. (1996), Regular spacing of drainage outlets from linear mountain belts, Basin Res., 8(1), 29-44, doi:10.1111/j.1365-2117.1996.tb00113.x.

Hughes, P. D., J. C. Woodward, and P. L. Gibbard (2006), Quaternary glacial history of the Mediterranean mountains, Prog. Phys. Geogr., 30(3), 334-364, doi:10.1191/0309133306pp0309133481ra.

Hughes, P. D., P. L. Gibbard, and J. C. Woodward (2011), Quaternary glaciation in the Atlas Mountains, North Africa, Dev. Quat. Sci., 15, 255-260, doi:10.1016/B978-0-444-53447-7.00076-3.

Koons, P. O. (1995), Modeling the topographic evolution of collisional belts, Annu. Rev. Earth Planet. Sci., 23, 375-408, doi:10.1146/annurev. ea.23.050195.002111.

Laville, E., and A. Piqué (1992), Jurassic penetrative deformation and Cenozoic uplift in the central High Atlas (Morocco); a tectonic model; structural and orogenic inversions, Geol. Rundsch., 81(1), 157-170, doi:10.1007/BF01764546.

Lugeon, M. (1901), Recherches sur l'origine des vallées des Alpes occidentales, Ann. Georgr., 10(54), 401-428, doi:10.3406/geo.1901.2148.

MADRPM (2000), Atlas de l'Agriculture, Colloque National de l'Agriculture et du Développement Rural, Minist. de l'Agric. du Dév. Rural et de Pêches Mar., Rabat, Morocco.

Makris, J., A. Demnati, and J. Klussmann (1985), Deep seismic soundings in Morocco and a crust and upper mantle model deduced from seismic and gravity data, Ann. Geophys., 3(3), 369-380.

Mattauer, M., P. Tapponier, and F. Proust (1977), Sur les mécanismes de formation des chaines intracontinentales. L'exemple des chaines atlasiques du Maroc, Bull. Soc. Geol. Fr., 7(3), 521-536.

McQuarrie, N. (2004), Crustal scale geometry of the Zagros fold-thrust belt, Iran, J. Struct. Geol., 26(3), 519-535, doi:10.1016/j.jsg.2003.08.009.

Missenard, Y., H. Zeyen, D. Frizon de Lamotte, P. Leturmy, C. Petit, M. Sébrier, and O. Saddiqi (2006), Crustal versus asthenospheric origin of relief of the Atlas Mountains of Morocco, J. Geophys. Res., 111, B03401, doi:10.1029/2005JB003708.

Missenard, Y., O. Saddiqi, J. Barbarand, P. Leturmy, G. Ruiz, F.-Z. El Haimer, and D. Frizon de Lamotte (2008), Cenozoic denudation in the Marrakech High Atlas, Morocco: Insight from apatite fission-track thermochronology, Terra Nova, 20, 221-228, doi:10.1111/j.1365-3121. 2008.00810.x

Montgomery, D. R., and M. T. Brandon (2002), Topographic controls on erosion rates in tectonically active mountain ranges, Earth Planet. Sci. Lett., 201(3-4), 481-489, doi:10.1016/S0012-821X(02)00725-2.

Naylor, S., and E. J. Gabet (2007), Valley asymmetry and glacial versus nonglacial erosion in the Bitterroot Range, Montana, USA, Geology, 35(4), 375-378, doi:10.1130/G23283A.1.

Oberlander, T. M. (1965), The Zagros Streams: A New Interpretation of Transverse Drainage in an Orogenic Zone, 168 pp., Syracuse Univ. Press, Syracuse, N.Y.

Oberlander, T. M. (1985), Origin of drainage transverse to structures in orogens, Binghamton Symp. Geomorphol. Int. Ser., 15, 155-182.

O'Callaghan, J. F., and D. M. Mark (1984), The extraction of drainage networks from digital elevation data, Comput. Vis. Graph. Image Process. 28(3), 323-344, doi:10.1016/S0734-189X(84)80011-0.

Ouimet, W. B., K. X. Whipple, and D. E. Granger (2009), Beyond threshold hillslopes: Channel adjustment to base-level fall in tectonically active mountain ranges, Geology, 37(7), 579-582, doi:10.1130/G30013A.1.

Ramsey, L. A., R. T. Walker, and J. Jackson (2008), Fold evolution and drainage development in the Zagros Mountains of Fars Province, SE Iran, Basin Res., 20(1), 23-48, doi:10.1111/j.1365-2117.2007.00342.x.

Teixell, A., M. L. Arboleya, M. Julivert, and M. Charroud (2003), Tectonic shortening and topography in the central High Atlas (Morocco), Tectonics, 22(5), 1051, doi:10.1029/2002TC001460.

Teixell, A., P. Ayarza, H. Zeyen, M. Fernandez, and M.-L. Arboleya (2005), Effects of mantle upwelling in a compressional setting: The Atlas Mountains of Morocco, Terra Nova, 17(5), 456-461, doi:10.1111/j.13653121.2005.00633.x.

Tesón, E., E. L. Pueyo, A. Teixell, A. Barnolas, J. Agusti, and M. Furió (2010), Magnetostratigraphy of the Ouarzazate Basin: Implications for the timing of deformation and mountain building in the High Atlas Mountains of Morocco, Geodin. Acta, 23, 151-165, doi:10.3166/ ga.23.151-165.

van der Beek, P., B. Champel, and J.-L. Mugnier (2002), Control of detachment dip on drainage development in regions of active faultpropagation folding, Geology, 30(5), 471-474, doi:10.1130/0091-7613 (2002)030<0471:CODDOD $>2.0$. CO;2.

Wigger, P., G. Asch, P. Giese, W. D. Heinsohn, S. O. El Alami, and F. Ramdani (1992), Crustal structure along a traverse across the Middle 
and High Atlas mountains derived from seismic refraction studies, Geol. Rundsch., 81(1), 237-248, doi:10.1007/BF01764552.

Willett, S. D. (1999), Orogeny and orography: The effects of erosion on the structure of mountain belts, J. Geophys. Res., 104, 28,957-28,981, doi:10.1029/1999JB900248
Zeyen, H., P. Ayarza, M. Fernàndez, and A. Rimi (2005), Lithospheric structure under the western African-European plate boundary: A transect across the Atlas Mountains and the Gulf of Cadiz, Tectonics, 24, TC2001, doi:10.1029/2004TC001639. 